\title{
Epidemics and outbreaks of peripheral nervous system disorders: II. Toxic and nutritional causes
}

\author{
Stéphane Mathis ${ }^{1}$ (1) $\cdot$ Antoine Soulages ${ }^{1} \cdot$ Jean-Michel Vallat $^{2} \cdot$ Gwendal Le Masson $^{1,3,4}$
}

Received: 21 August 2020 / Revised: 28 August 2020 / Accepted: 2 September 2020 / Published online: 11 September 2020

(c) Springer-Verlag GmbH Germany, part of Springer Nature 2020

\begin{abstract}
Peripheral neuropathies have various causes, both infectious and non-infectious. When we think of "epidemics", we often refer to an infectious or even post-infectious origin. Nevertheless, the history of mankind is marked by episodes of epidemics of peripheral neuropathies of non-infectious nature, either of nutritional or toxic origin: we present here the main causes of such epidemics.
\end{abstract}

Keywords Alcohol $\cdot$ Beriberi $\cdot$ Tropical ataxic neuropathy $\cdot$ Lead $\cdot$ Arsenic $\cdot$ Hexacarbons

$\begin{array}{ll}\text { Abbreviations } \\ \text { ARW } & \text { American revolutionary war } \\ \text { EMS } & \text { Eosinophilia-myalgia syndrome } \\ \text { FDA } & \text { Food and drug administration } \\ \text { JG } & \text { Jamaica ginger } \\ \text { L-TRP } & \text { L-Tryptophan } \\ \text { PN } & \text { Peripheral neuropathy } \\ \text { PNS } & \text { Peripheral nervous system } \\ \text { PP } & \text { Pellagra preventis } \\ \text { TAN } & \text { Tropical ataxic neuropathy } \\ \text { TOCP } & \text { Tri-ortho-cresyl-phosphate } \\ \text { WHO } & \text { World Health Organization }\end{array}$

Introduction

Although many epidemics of peripheral neuropathy (PN) were due to infectious or post-infectious diseases, non-infectious disorders may also be incriminated. For example, two

Stéphane Mathis

Stephane.mathis@chu-bordeaux.fr

1 Department of Neurology, Nerve-Muscle Unit, CHU Bordeaux (Pellegrin University Hospital), Place Amélie Raba-Léon, Bordeaux 33076, France

2 Department of Neurology, National Reference Center for 'Rare Peripheral Neuropathies', University Hospital, 2 Avenue Martin Luther King, Limoges 87042, France

3 University of Bordeaux, Bordeaux U1215, F-33000, France

4 INSERM, Neurocentre Magendie, 'Physiopathologie de La Plasticité Neuronale', Bordeaux U1215, F-33000, France of the main current causes of PN worldwide are diabetes mellitus and alcohol consumption, both being considered as real epidemics (or even endemics/pandemics) from an epidemiological point of view. Other frequent forms of PN are drug-induced PN (chemotherapy,.etc.). However, this paper will not deal with drug-induced and diabetic PN, but only focus on alcohol-induced PN and other lesser known causes of toxic and nutritional PN giving rise to epidemics in the past.

\section{Alcohol consumption and peripheral neuropathy}

\section{The history of alcoholism}

Since ancient times, alcoholic beverages play an important social role across the globe. The first archaeologic evidence of production and consumption of fermented beverage may go back 13,000 years (Neolithic), cereal-based beer having been developed by the Natufians in the Near East (Israel) [1]. Fermented beverages such as beer and wine were an essential part of the gracious way of life in many ancient civilizations (Egypt, Greece, India, China, Roma, etc.) [2], and even today. Primitive forms of distillation were developed in ancient Mesopotamia (first millenium BC), and some forms of distilled alcohol were probably known to the ancient Indians and Chinese, as well as ancient Greeks [3]. There was also evidence of true alcohol distillation (and the discovery of the flammable properties of alcohol vapors) in the Arabian alchemical treatises of the Middle Ages [4]. It 
is interesting that the term "alcohol" comes from the Arab "al-kuhll" that means "anti-monite" ("stibnite"): "alcohol" was then generalized to any powder obtained by triturating a material or any liquid obtained by boiling down (especially "spirit-of-wine"). First regarded as a poison, spirit-of-wine (corresponding to ethanol) was finally considered as a remedy or a global panacea (known as "aqua vitae" or "ardent spirit"), given in Europe as an invigorator for workers or soldiers since the Middle Ages (especially since the eleventh century) [5]. The consumption of ardent spirits (more than wine and beer) has led to excess mortality in Europe since the seventeenth century; it then spread throughout the United States after the American Revolutionary War (ARW) where spirits were distributed to the US troops (to combat fatigue): spirits were then adopted by US soldiers who contributed to generalize consumption in the USA after ARW. This excessive consumption became a serious public health problem in both Europe and the USA and, at the beginning of the nineteenth century, American temperance societies were established in which members took a pledge to abstain from drinking distilled beverages [5]. Although the term "alcoholism" was proposed by the Swedish physician Magnus Huss (1807-1890) in 18 [6, 52], the abuse of alcoholic beverages is very old. Since the earliest times, the immoderate use of these beverages has attracted the attention of lawmakers, as observed in ancient Greece when Draco (650-600 BC) punished drunkenness with death, one of the many punishments of the 'Draconian constitution' that were finally repealed by Solon (640-558 BC) some years later [5]. At the present time, alcohol consumption is still a public health problem in most countries, as mentioned by the World Health Organization (WHO) in 2018: "The harmful use of alcohol is one of the leading risk factors for population health worldwide and has a direct impact on many health-related targets of the Sustainable Development Goals (SDGs), including those for maternal and child health, infectious diseases (HIV, viral hepatitis, tuberculosis), non-communicable diseases and mental health, injuries and poisonings". Worldwide alcohol annual consumption in 2016 was equal to $6.4 \mathrm{~L}$ of pure alcohol consumed per person aged $>15$ [7].

\section{The main steps in the history of alcohol-induced peripheral neuropathy}

It had long been observed that drinking alcoholic beverages may result in mental or physical health problems, including neurological disorders such as sensory deficits, tremors, seizure, delirium tremens or dementia [5]. In 1822, the American physician James Jackson (1777-1867) described, under the term "arthrodynia a potu", what could be considered as the first reports of alcohol-induced PN after consumption of ardent spirits, the patients usually presenting symptoms as follows: "It commences with pains in the lower limbs, but especially in the feet, and afterwards extend to the hands and arms"; "the pain is more severe in the feet and hands, than in the upper parts of the limbs"; "at length the hands and feet become nearly useless, the flexor muscles manifesting, as in other disease, greater power than the extensors". He added that the effect of "abstinence from spirituous liquors of every kind, either in the form of medicine, or in any other form" is "gradual" and "great", and used also "opium in sufficient quantities to relieve the pain at night and procure sleep" [8]. Finally, it was also probably one of the first detailed report of $\mathrm{PN}$, although Jackson said that "the paralysis is to be referred to some affection of the muscles, and not to the nerves, as in common paralytic cases" [8]. A few years later, having not observed any abnormality by macroscopically studying the peripheral nerves of five patients with chronic alcoholism and neuropathic pain, Huss suggested that the origin of what he described as "hyperesthesic alcoholism" could be in the spinal cord [6]. Although Huss mentioned the symmetric pattern of these painful symptoms (described as "tinglings" and "burning"), he did not note motor weakness that was mild in his cases [6].

Etienne Lancereaux (1829-1910) was the first to thoroughly study "alcoholic paralysis", giving more details on the pathological lesions of the nervous system and being the first to suggest a link between it and his observed alterations of peripheral nerves [5, 9]. Emile Théodore Leudet (1825-1887) also studied many cases of "alcoholic paralysis" associated with "motor incoordination" (probably in part from cerebellar origin), he thought to be of spinal origin ("spinal paralysis"); however, he added that "in at least some cases of chronic alcoholism, the peripheral nervous accidents were due to an anatomically demonstrable lesions of these nerve branches", as well as in muscles [5, 10]. The same observation of "drunkard's" or "alcoholic paraplegia" was made in England since 1867 by Samuel Wilks (1824-1911). In 1868, Reginald Edward Thompson (1834-1912) described five patients: autopsy was performed in one case showing "limited swelling of the posterior columns" of the spinal cord and observing that the peroneal nerve was "diminished in size" [11]. In 1883, Thomas Robinson Glynn (1841-1931) noted the abolition of the patellar reflexes [12]. In 1884, Carl Franz Moeli (1849-1919) observed pathological lesions of the femoral nerves [13], Walter Baugh Hadden (1856-1893) reported lesions in sciatic nerves (with absent deep tendón reflexes) [14] and Julius Dreschfeld (1845-1907) observed such lesions in both femoral and sciatic nerves [15]. The same year, JeanMartin Charcot (1825-1893) highlighted that such patients also frequently presented vasomotor disturbance of the lower limbs and also sometimes cognitive disorders such as loss of memory [16]. For the latter, it is probable that Charcot, like Wilks in 18 [17,68] described some cases of what will be later called Wernicke-Korsakoff's syndrome, a pathology 
that was fully detailed as "diffuse encephalitis" (ophthalmoplegia and drowsiness but no sign of PN) by Charles Gayet (1833-1904) [18], "polioencephalitis haemorrhagica superioris" by Carl Wernicke (1848-1905) [19], then "psychosis polyneuritica seu cerebropathia psychica toxoemica" by Serguei Korsakoff (1864-1900) [20-22] Nowadays, we know that this complex brainstem syndrome (frequently associated with alcohol-induced PN) is caused by thiamine deficiency (Gayet-Wernicke's encephalopathy) or the combined effects of thiamine deficiency and excessive alcohol consumption (Korsakoff syndrome) [23]. In 1885, William Marc Oettinger (1856-?) clearly considered "alcoholic paralysis" as "multiple neuritis" (polyneuropathy) with pathological lesions strictly affecting the peripheral nerves (sparing the spinal cord) [24]. Alfred Gombault (1844-1904) was one of the first to fully study the pathological stages in the peripheral nerves of patients with "alcoholic paralysis", showing Wallerian degeneration and rapid destruction of both myelin and axons (Fig. 1) [25].

Alcohol-related PN usually presents as chronic polyneuropathies involving sensory, autonomic, and motor nerves [23]. Usually classified as a progressive, predominantly sensory axonal length-dependent polyneuropathy (with motor weakness in the more severe forms), acute/subacute PN [26] or small fiber neuropathy were also described [23]. Another special neurological complication of alcohol consumption (even if not the only cause) was described in 1957, sometimes referred as "acrodystrophy of Bureau and Barrière" [27]. The most important risk factor for alcohol-related PN is the total lifetime dose of ethanol (although other risk factors have been identified: genetic, male gender, and type of alcohol consumed); [28] nutritional deficiency (thiamin, niacin, cobalamine) can also exacerbate alcoholic PN [23]. The overall prevalence of polyneuropathy (whatever the cause) in the general population is around $1 \%$, rising to $7 \%$ in the elderly: [29] the prevalence of alcohol-induced PN is high in chronic alcohol abusers (44.2-46.3\%) and represents 10\% amongst all patients with PN [28].

\section{Epidemics of nutritional peripheral neuropathy}

\section{Vitamin B1 deficiency}

During the first third of the seventeenth century, the Dutch physician Jacobus Bontius (1592-1631) reported on mysterious epidemics of paralysis that natives of India called "beriberi" [30], although John MacGowan (1835-1922) thought it was mentioned under the term "Kioh-Ki" in a fundamental treatise on Chinese medicine ("Huángdì Nèijīng) dating from $2600 \mathrm{BC}$ : a more detailed description of beriberi as "Kak-ke" (from the Chinese word "Kiaku" for "leg" and "ki" for "disease"), appeared in another book ("Sen-Kin-ho") written by the Chinese physician Son-Shi-Baku (640 AD) $[31,32]$. The most commonly accepted hypothesis about the word "beriberi" is that it would mean "weak, weak" in Singhalese (from "bhayree" meaning "weak"), although alternative explanations were also suggested [33]. This disease was called "bharbari" in India and "buhr bari" (meaning "marine asthma") in Arabia and Madras (India), later translated into "barbers" in English then "barbiers" in French [33], this later word being also used at least during two centuries in the European medical literature [31]. These various terms had unfortunate consequences that contributed to maintaining (if not increasing) the initial misunderstanding

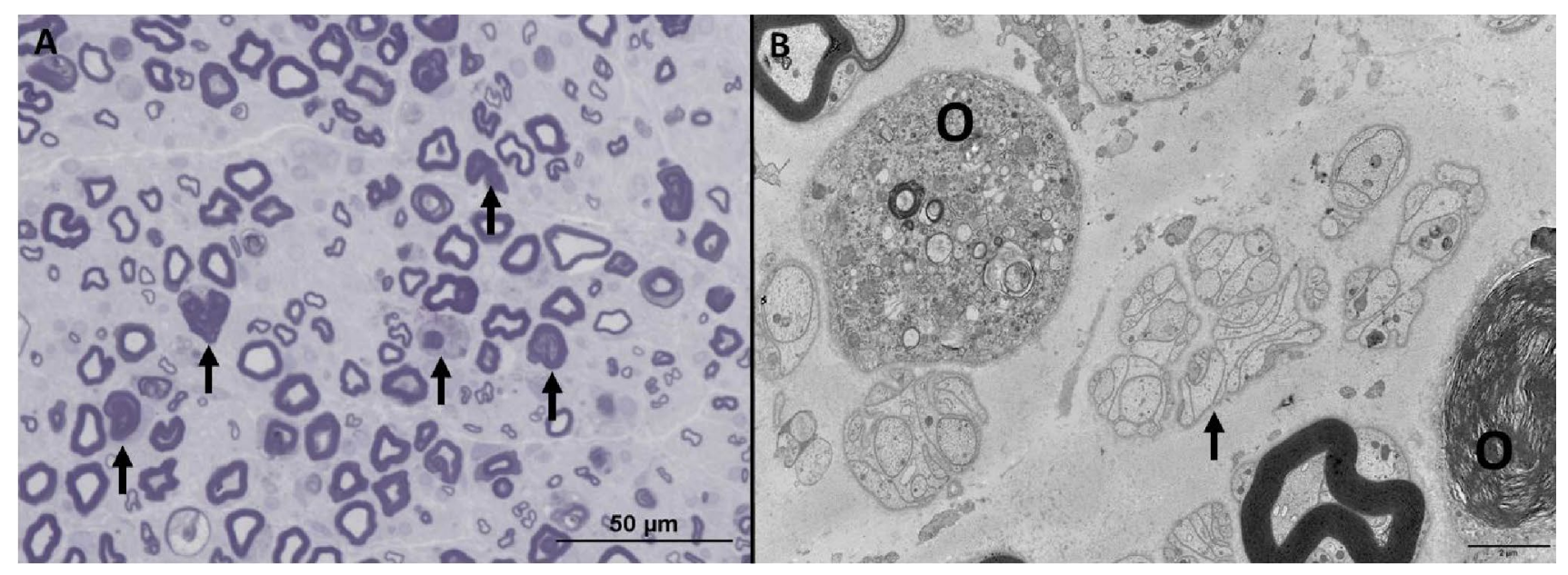

Fig. 1 Alcohol-induced peripheral neuropathy (personal case). a Semi-thin transverse section of the sural nerve. Early Wallerian degeneration; no rarefaction of myelinated fibers, but presence of numerous axonal lesions (ovoids) which are composed of disinte- grated myelin segments and disrupted axons (arrows). b Electron microscopy transverse section of the sural nerve. Several ovoids (0); in unmyelinated Schwann cell cytoplasms, many axons have disappeared leaving empty bands of Schwann cells (arrow) 
about beriberi. Actually, Bontius used "beriberi" only for patients with paralysis, but never used it for those with generalized edema (due to cardiac involvement), the other main symptom of the disease that Bontius, however, mentioned as "frequent in India" [30]. In fact, beriberi has long time been confused with other diseases, so various other terms were proposed to describe it, such the "hydrope asthmatico" of the Scottish Surgeon Colin Rogers (referring to the generalized edema then dyspnea observed in beriberi): [34] it was not until the beginning of the nineteenth century that "beriberi" was linked to generalized edema [35]. At that time, many authors called the severe paralytic forms "barbiers" (in Europe) or "kak-ke" (in Japan), whereas the less severe motor forms with edema were considered as "beriberi"
[35]. Nowadays, beriberi is divided into three forms: "dry beriberi' (characterized by a sensorimotor, distal, axonal PN often associated with calf cramps, muscle tenderness, and burning feet), 'wet beriberi' (association of PN and high output congestive heart failure), and' infantile beriberi' (observed between 2 and 6 months of age, it may present with the cardiac, aphonic, or pseudomeningitic forms) [36].

Despite the fact that beriberi was endemic in many areas over many centuries (especially in Asia, but also in Africa then America; Fig. 2), its origin was unknown before the turn of the twentieth century. In the seventh century, Son-Shi-Baku thought it was produced by a gaseous poison coming from the ground (under the influence of cold, heat, wind and humidity), penetrating through the
Fig. 2 Major beriberi outbreaks in the world in 1906. This map is extracted from "Jeanselme E. Le béribéri. Paris: Masson \& Cie-Gauthier-Villars, 1906; pages 16-17" (freely available via the "Medical Heritage Library")

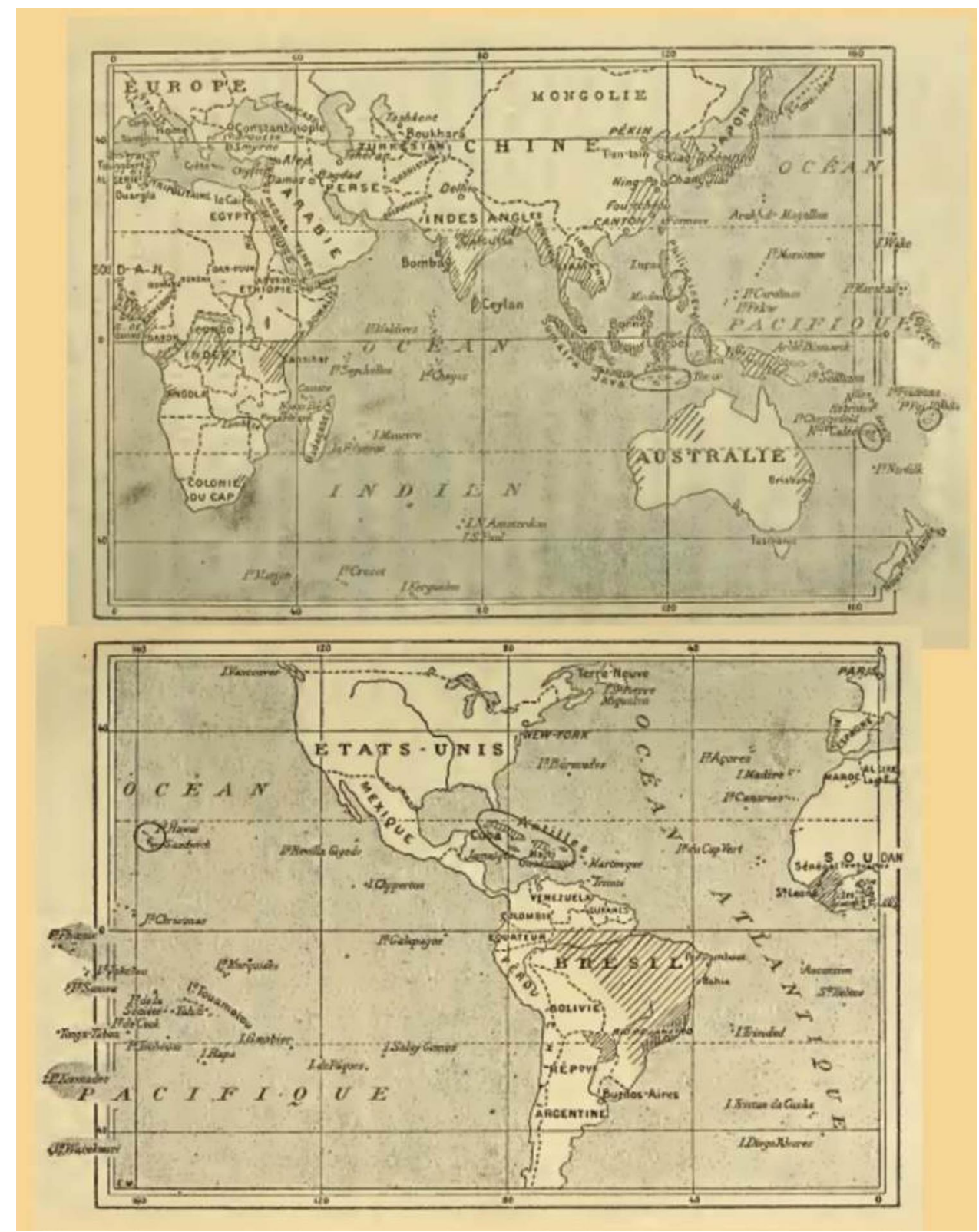


feet, up to the legs and then to the rest of the body [35]. Many cases were also reported as "sailing polyneuritis" ("nautical beriberi") in the European sailboats coming from endemic areas and making long non-stop crossings without replenishing supplies of fresh food [35]. In 1872, Baron Kanehiro Takaki (1849-1920) entered the Japanese Navy where he observed many fatal cases of beriberi, a subject he became more interested in after 1880, when he came back from a 5-year stay in England where he was a student of William Willis (1837-1894). Although Albrecht Wernich (1843-1896) was probably the first to clearly suggest a causal connection between beriberi and an exclusive diet of rice [37], Takaki discovered that "the nitrogenous substances contained in the food were not sufficient to maintain nitrogen metabolism, but that the food contained too much carbohydrate" and that "finally, the greater the difference in these proportions (between nitrogen and carbon) the more beriberi occurred, and the lesser the difference the less beriberi occurred" [38]. From 1884, Takaki eliminated white rice from the Navy's diet, tested a better balanced nitrogen-carbon diet and observed a dramatic reduction in the number of cases of beriberi (which he mistakenly attributed, 1 year later, to the nitrogen-rich diet) [39]. When barley (mixed with rice) was introduced into their rations, the toll that beriberi took on Japanese soldiers declined dramatically [40]. However, in 1883 , while beriberi was still considered by many physicians as an infectious disease, João Batista de Lacerda (1846-1915) thought he found the "Bacillus beribericus" [41], as did Masanori Ogata who claimed he discovered "Micrococcus beribericus": this was quickly refuted by Robert Koch (1843-1910) and Shibasaburo Kitasato (1853-1931) who failed to repeat the experiment and concluded that such organisms did not cause beriberi [40]. The Dutch physician Christiaan Eijkman (1856-1930), was initially convinced that beriberi might be of bacterial origin, and decided to study it in chickens. He accidentally discovered that chickens that were fed polished rice (purchased for the army) developed "polineuritis galliniarium", a disease whose symptoms resembled beriberi [42]. Eijkman and Adolphe Vordermann (1944-1902) thought there was an "anti-beriberi factor", but failed to isolate it [43]. In 1911, Casimir Funk (1884-1967) finally isolated the substance (from rice husk) he called "amine" (corresponding to thiamine) and thought there were many other similar substances (essential to life) he called "vitae aminae" (later shortened in "vitamine") [44]. But only Eijkman was honoured with the Nobel Prize (1929) [45] for his work on beriberi [43]. Nowadays, we know that thiamine deficiency may be observed in other conditions such as chronic alcoholism, persistent vomiting, anorexia, or after bariatric surgery [36-46].

\section{Pellagra}

At the beginning of the eighteenth century, the first cases of a new disease called "mal de la rosa" ("rose sickness") were reported in Asturias (Spain), first by François Thiéry (1719-?) in 17 [47, 55] then by Gaspar Casàl in 1762 [48]. This disease became one of the major health and demographic problems of Italy at the end of the eighteenth century, where it was named "pellagra" ("pel" meaning "skin" and "agra" meaning "rough" in the Italian dialect from Bergamo) by Francesco Frapolli (?-1773) [49]. This affection is characterized by the "four D's": dermatitis (reddish-brown hyperkeratotic rash), diarrhea, dementia and death. Also called "plague of corn", pellagra has been quickly linked to high maize and low protein diets, and was rampant in some parts of Europe, especially in Southern Europe, where maize became more common as a staple food during the eighteenth century, as in Northern Italy where the poor diet of the Italian peasantry was almost exclusively based on maize flour such as "polenta". In the early 1900 s, pellagra was also rampant in the southern USA [50].

Pellagra, as a disease of poverty and social inequality, was initially associated with scorbut and leprosy because of the skin lesions, and such patients (as with leprosy) were victims of social exclusion. Many theories were put forward to explain it (maize diet with little or no milk, meat or fresh vegetable supplements; spoiled or rotten grain; disease spread by insects; bad heredity; overall consequence of poverty) before the true etiology of pellagra was found in 1914-1915 by the American physician Joseph Goldberger (1874-1929), although his conclusions were only accepted nearly 20 years later, in the 1940's (when pellagra was completely eliminated from the US): pellagra is caused by long-term insufficient niacin (also called vitamin-PP, for "Pellagra Preventis") and its amino acid precursor (tryptophan intake), high-maize being usually deficient in such substances. In 1952, pellagra was also recognized as a complication of isoniazid therapy [51]. Moreover, because excessive alcohol consumption is also a known risk factor of pellagra, it may be difficult to diagnose pellagra in alcohol-dependent patients where it frequently coexists with PN (32\%), Wernicke's encephalopathy (29\%) and seizure (16\%) [52].

Peripheral nerve changes have been associated with pellagra, although PN seems to be more characteristic of beriberi than pellagra. Sensory disturbances (usually mild) consist of paraesthesiae and numbness. Occasionally with muscular wasting and loss of deep tendon reflexes [53]. In 1881, Jules Dejerine (1849-1917) was the first to observe extensive degeneration of the myelin sheath in the cutaneous nerves of two patients with pellagra [54]. In 1940, Samuel Alexander Kinnier Wilson (1878-1937) studied 13 patients with pellagra, reporting practically constant peripheral nerve 
changes: swelling or thinning of myelin sheaths, fragmentation of axons, oedema of nerve fibers and bundles, and thickening of the epi- and peri-neurium [55]. Despite these observations, PN in pellagra may stem from other concomitant B-group vitamin deficiencies, such as thiamine [36].

\section{Tropical ataxic neuropathy}

Between 1883 and 1897, Henry Strachan (Senior Medical Officer in Jamaica) observed 510 cases of " a form of multiple neuritis prevalent in the West Indies" [56, 57]. characterized by "numbness and burning heat in the palms of the hands and the soles of the feet", often "accompanied by cramps"; hyperpigmentation of the skin was also sometimes observed [56]. "Impaired vision and hearing", "extreme wasting of the muscular system" (involvement of lower then upper extremities, claw hand deformity, depressed deep tendon reflexes) and sensory deficits were observed in the more advanced stage of the disease (sometimes with respiratory impairment) [56]. The enigmatic "Strachan's syndrome" (or "Strachan-Scott syndrome") was characterized pathologically by variable combinations of damage to the anterior horns and posterior columns of the spinal cord, peripheral nerves (predominantly the sensory nerves; Fig. 3), optic nerves and cochlear nerves [58]. Called "tropical ataxic neuropathy" (TAN) in 19 [59] it is characterized by predominantly sensory ataxic polyneuropathy, the cases with predominant spastic paraplegia nowadays being ascribed to "Konzo" [60]. A longstanding condition in the Caribbean, but other cases have been reported in Africa, Asia and Latin America (including European prisoners of war) during the

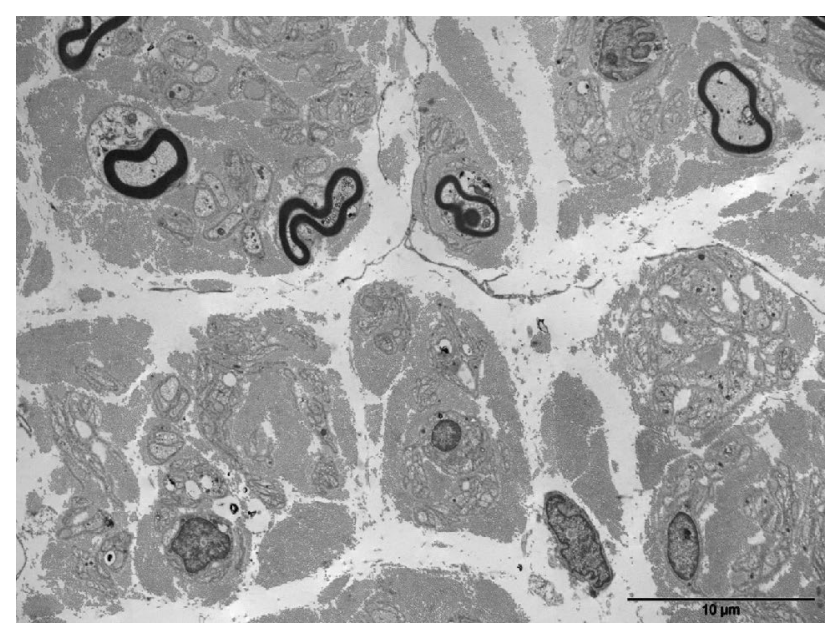

Fig. 3 Nutritional peripheral neuropathy (personal case). Sural nerve biopsy (electron microscopy; transverse section) of a patient with tropical ataxic neuropathy, showing severe loss of myelinated and unmyelinated axons, absence of any demyelinating or remyelinating process and no sign of regeneration twentieth century [59]. Its nutritional origin was suggested since 1911, and thiamine/riboflavin deficiency was proposed in 1959 [59]. But a role of the consumption of roots of cassava (Manihot esculenta), one of the largest source of carbohydrates in the tropics, was also suspected since 1930: so the chronic, monotonous consumption of cassava meals associated with minimal protein supplementation was proposed to explain TAN [60].

\section{Cuban neuropathy}

From 1991 to $1993,50,000$ patients were after by the socalled "Cuban neuropathy" (spreading from West to East of Cuba), characterized by the subacute occurrence of symptoms including retrobulbar optic neuropathy, predominantly sensory PN and dorsolateral myeloneuropathy [61], sometimes mimicking TAN. On sural nerve biopsy, moderate or severe axonal damage was observed in $73 \%$ of the cases, with a predominant loss of myelinated fibers in $92 \%$ of the cases [61]. Evidence of thiamine deficiency was found in up to $70 \%$ of the patients, and the majority of them responded biochemically to a daily oral multivitamin supplement containing thiamine [62]. Two types of neuropathy were observed: the optic form (prevalent in men; subacute onset) and a peripheral form, (prevalent in women; predominantly sensory PN, with posterior spinal cord involvement in some cases, with or without concurrent optic neuropathy). Cuban and international scientist proposed a toxic and nutritional hypothesis to explain it (injuries to the mitochondrial oxidative phosphorylation pathway, nutritional deficiencies, excitotoxicity, and dysfunction of the blood-brain barrier) [63] .

\section{Myanmarese neuropathy}

Between 2008 and 2014, an increasing number of Myanmarese refugees admitted in Malaysia with acute/subacute predominantly sensorimotor axonal PN was observed: most of them were malnourished, with a preceding history of starvation of 2-4 weeks before onset of symptoms [64]. This clinical picture was closed to the neurological complications of thiamine deficiency, as observed in other refugees [65] or prisoners [66], so a nutritional cause was suggested. Moreover, folate and vitamin B12 deficiencies were also detected in $31.5 \%$ of the patients, and most of them improved after supportive treatment with appropriate vitamins supplementation [64]. However, the same patients also usually had at least one additional presenting symptom such as fever, lower limb swelling, vomiting, abdominal pain, or difficulty in breathing. All these findings suggested the presence of PN related to nutrition against a backdrop of other possible 
environmental factors such as infections, metabolic disorders, or exposure to unknown toxin [64].

\section{Epidemics of toxic peripheral neuropathy}

\section{Lead}

Naturally present in the Earth's crust, traces of lead exposure have been found in Neanderthal children [67]. However, lead becomes highly toxic once mined, transformed into manmade products and dispersed throughout the environment. In the Middle East and Egypt, lead was used 6000 years ago, and lead toxicity was recognized since at least $2000 \mathrm{BC}$ with endemic "chronic plumbism" (the main reported manifestations being colic, anemia and gout, although neurological manifestations are usual). This was also observed by the ancient Greeks and Romans, the latter being the first mass distributors of lead (using it for cooking utensils and pots, wine urns, plumbing and aqueducts, etc.) [68]. Later, leadbased additives were used to sweeten wine, giving epidemics of "colic" during the Middle Ages, and lead poisoning was considered as a "plague" in Europe and America between the fifteenth and eighteenth centuries [68]. Since the nineteenth century and the industrial revolution of Western countries, many workers also absorbed lead from inhalation of fine dust or through the skin [68]. Occupational exposure to lead nowadays remains a problem in developing countries, but is also still of concern in some areas of Western countries, especially in children [69].

Nicander of Colophonius (second century BC) was probably the first to report lead paralysis, and Paracelsus (1493-1541) wrote about "morbis metallicis", but the first detailed clinical descriptions of lead paralysis were made by Louis Tanquerel des Planches (1810-1862) [70], Guillaume Duchenne de Boulogne (1806-1875) [71] then Augusta Dejerine-Klumpke (1859-1927) in the second half of the nineteenth century [72]. Lead paralysis may be focal or generalized: for the focal forms, the most common one affects the upper limbs, usually first beginning by involving common extensors of the fingers, giving the classical aspect of a patient "making the horns", as described by Duchenne de Boulogne [71, 72].

\section{Arsenic}

Arsenic is known to be a traditional poison, called "poudre de succession" ("powder of inheritance") in France under the reign of Louis XIV [73], and was also used in traditional Chinese medicine since at least 4000 years ago [74]. In Europe, it was part of the treatment of syphilis or other disorders in the nineteenth century [74]. Today, it is still widely used in industry (especially in the production of pesticides, herbicides, wood preservatives, and semiconductors) and represents a public health issue in some areas [74].

Although acute arsenic poisoning produces arterial hypotension, encephalopathy and organ failure (leading to death at high doses), chronic exposure is characterized by skin involvement (keratosis and pigmentation) and other disorders including PN [74]. One of the most famous epidemics of arsenic-induced polyneuropathy was described in England in 1900-1901: first considered as alcohol-induced PN (because "peripheral neuritis is unfortunately a very common affection in Lancashire among alcoholics, and for at least 20 years has been a prolific cause of paralysis. The subjects affected are almost invariably beer drinkers"), this mysterious epidemic (enough to fill hospitals with beer drinkers) was finally due to the consuming of unsuspected and undetected quantities of arsenic in the beer because of contaminated barley malt used unwittingly by brewers [75].

\section{Hexacarbon solvents}

There are many examples of outbreaks of PN due to hexacarbon solvents (such as n-hexane and methyl-n-butylkenone), first observed in Japan in the 1960's then in Europe and the US. Hexacarbon exposure leads to subacute-chronic dying-back PN, sometimes with giant axons and demyelinating signs on nerve biopsy (Fig. 4) [76]. These solvents were especially used in shoe-making and the printing industry. Another common cause of hexacarbon PN is the deliberate inhalation of the vapors of lacquers or glue ("glue-sniffing") [77].

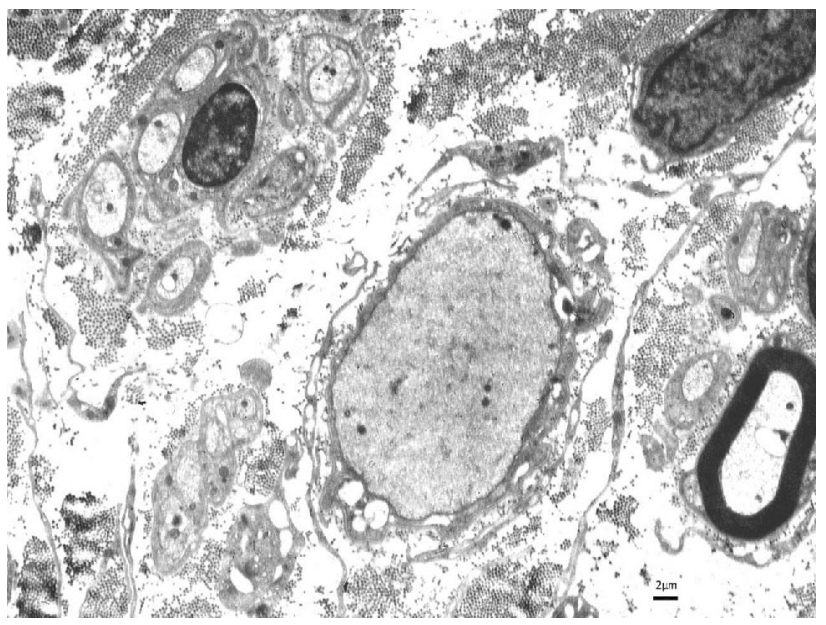

Fig. 4 Toxic peripheral neuropathy (personal case). Sural nerve biopsy (electron microscopy; transverse section) of a patient with n-hexane neuropathy, showing significant swelling of one axon due to the accumulation of packed filaments (the myelin sheath has completely disappeared) 


\section{Tri-ortho-cresyl-phosphate}

Tri-ortho-cresyl-phosphate (TOCP) was a famous cause of an outbreak of PN in the 1930's. "Jamaica ginger" was an alcoholic extract of ginger available as "medicine" in US drug stores since 1863. During prohibition, some Jamaica ginger (JG) extract was legally marketable as a carminative [78]. But illicit brands (made with legal JG) were created to circumvent prohibition (especially in the Southern and Midwestern US): it was highly adulterated JG beverages ("Jake") containing various substances, sometimes including TOCP used as a liquid plasticizer (TOCP was present in up to $2 \%$ of the beverages).

The tragic consequence of this massive poisoning was severe PN with gait disturbance, called "Jake leg": it also inspired some American popular music as the "Jake Walk Blues" of the Allen Brothers (1930) [78]. Similar cases were observed in Sri Lanka in 1981, due to the consumption of gingili oil contaminated with TOCP [79].

\section{Coyotillo}

Due to the consumption of the fruits of coyotillo (Karwinskia humboldtiana), a poisonous shrub of the buckthorn family, outbreaks of "buckthorn polyneuropathy" (giving generalized flaccid paralysis clinically mimicking GBS, sometimes leading to death by respiratory failure) were observed in 106 Mexican soldiers in 1918 and 16 Mexican children in 1951 [80]. It may result from a disruption of the metabolic activity of Schwann cells [80].

\section{Refined aniline}

The "toxic oil syndrome" was another outbreak observed in nearly 20,000 people in Spain (1981), due to the consumption of oils containing refined aniline denatured rape seed oil: the main symptoms were eosinophilia, myalgia and pulmonary edema in the acute period, then a multisystemic disease including PN in some cases [81].

\section{L-Tryptophan}

During the summer of 1989, an epidemic of what was called "eosinophilia-myalgia syndrome" (EMS) was observed in New Mexico (affecting around 1500 individuals, with 36 deaths): the patients presented eosinophilia and first complained of intense myalgia, followed by chronic cutaneous lesions, progressive PN and myopathy [82]. EMS was associated with ingestion of L-tryptophan (L-TRP) contained in dietary supplements manufactured in a Japanese plant using genetically engineered bacteria: removal of L-TRP from the market was followed by swift resolution of the EMS outbreak. Since the Food and Drug Administration (FDA) lifted the L-TRP import alert in 2005, only one sporadic cases of EMS was reported in 2011 [83].

\section{Agent orange}

Agent Orange (AO) was an herbicide used during the Vietnam War by the US military to clear plants and trees: it was named "orange" after the orange-striped barrels in which it was shipped [84]. AO was a 1:1 mixture of 2,4-dichlorophenoxyacetic (2,4-D) acid and 2,4;5-tricholorophenoxyacetic $(2,4,5-\mathrm{T})$ acid, but its toxicity was mainly due to the high concentrations of toxic contaminant, 2,3,7,8 tetrachlorodibenzodioxin (dioxin). In 1961, the program code named "RANCH HAND" was approved by President John Fitzgerald Kennedy (1917-1963). The objective was to aerially disseminate herbicides in the Republic of Vietnam, with two missions: defoliation and crop destruction [84]. Six herbicides were used (Orange, Purple, Pink, Green, White and Blue), but AO was the primary defoliant: [84] between 1965 and 1970,> 40 million liters of AO were sprayed by the US Air Force in South Vietnam [85].

Health concerns about the use of AO emerged in the 1950 's, mainly in workers (in 2,4-D and 2,4,5-T plants) who developed various manifestations: chloracne and mucous membrane irritation, hepatotoxicity, neuromuscular problems, psychologic alterations and porphyria cutanea tarda [86]. In October 1978, the US Air force conducted an epidemiological study of AO exposure on their "Ranch Hand" personnel in Vietnam, finally published in December 1982 [87]. However, despite it was observed signs/symptoms consistent with PN in US veterans exposed to AO [87], it concluded that "There is insufficient evidence to support a cause and effect relationship between herbicide exposure and adverse health in the Ranch Hand group at this time" [84]. In a later study (follow-up of the "Ranch Hand veterans" between 1992 and 1997), a statistically significant increased odds of probable PN was observed but the authors remained cautious in their interpretation "about the possible association between exposure to dioxin in Operation Ranch Hand and subsequent development of peripheral neuropathy" [88]. Two years later, a Korean study observed high frequency of PN (odds ratio: 2.39) in Korean Vietnam veteran compared to non-Vietnam veterans [89]. In another Korean study, exposure to AO was "associated with a significantly higher prevalence of cancers (colon cancer, leukemia, and multiple myeloma), circulatory diseases (hypertension, cerebral infarction, and peripheral vasculopathy), neuromuscular diseases (peripheral neuropathy, multiple nerve palsy, and multiple sclerosis), skin diseases, and lipidemia" [90]. 


\section{Conclusion}

The causes of PN are numerous, both sporadic and epidemic. Through the writings of our forefathers, including those from ancient times, we know that many epidemics of PN have affected mankind, from various origins (infectious or not) and to a greater or lesser extent. In view of the current COVID-19 pandemic affecting the entire world, it is, therefore, highly likely that other epidemics (of whatever the cause) may re-occur, and it is to be hoped that the lessons of the past will enable us to better understand the future.

Funding No targeted funding reported.

\section{Compliance with ethical standards}

Conflicts of interest The authors declare that they have no conflict of interest.

Ethical standard statement This paper does not contain any studies with human participants or animals performed by any of the authors.

\section{References}

1. Liu L, Wang J, Rosenberg D, Zhao H, Lengyel G, Nadel D (2018) Fermented beverage and food storage in 13,000 y-old stone mortars at Raqefet Cave, Israel: investigating Natufian ritual feasting. J Archaeol Sci Rep 21:783-793

2. McGovern PE (2003) Ancient wine: the search for the origins of viniculture. Princeton University Press, Princeton

3. Morewood S (1838) A philosophical and statistical history of the inventions and customs of ancient and modern nations in the manufacture and use of inebriating liquors; with the present practice of distillation in all its varieties: together with an extensive illustration of the consumption and effects of opium, and other stimulants used in the East, as substitutes for wine and spirits. William Curry, Jun \& Cie and William Carson, Dublin

4. Al-Hassan AY. Alchemy, chemistry and chemical technology. In: Al-Hassan AY, Ahmed M, Iskandar AZ, eds. The different aspects of islamic culture-Science and technology in Islam (part 1): the exact and natural sciences Paris: UNESCO, 2001: 41-84

5. Lancereaux E. Alcoolisme. In: Baige-Delorme, Dechambre A, eds. Dictionnaire encyclopédique des sciences médicales ADHALG. Paris: P. Asselin, Victor Masson \& Fils, 1864: 615-704

6. Huss M. Chronische Alkoholskrankheit oder alcoholismus chronicus. Ein Beitrag zur Kenntnis der Vergiftung-krankheiten, nach eigener und anderer Erfahrung. Stockholm-Leipzig: C. E. Fritze, 1852

7. WHO. Global status report on alcohol and health 2018. Geneva: World Health Organization, 2018

8. Jackson J (1822) On a peculiar disease resulting from the use of ardent spirits. N Engl J Med Surg 11:351-353

9. Lancereaux E (1865) Etudes sur les altérations produites par l'abus des boissons alcooliques. Gaz Hebd Med Chir 2:435-439

10. Leudet E (1867) Etude clinique de la forme hyperesthésique de l'alcoolisme chronique, et de sa relation avec les maladies de la moelle. Arch Gen Med 9:5-39
11. Thompson RE (1868) On paralysis of the extensors. Med Chir Trans 51:241-247

12. Glynn TR. Cases of alcoolic paraplegia. Liverpool Med Chir J 1883

13. Moeli C (1884) Statistisches und klinisches über Alcoholismus. Charite Ann 9:524-548

14. Hadden WB (1884) Two fatal cases of alcoholic paralysis. Lancet $124: 735$

15. Dreschfeld J (1884) On alcoholic paralysis. Brain 7:200-211

16. Charcot JM (1884) Les paralysies alcooliques. Gaz Hop Civ Milit 46:785-786

17. Wilks S (1868) Paraplegia. Med Times Gaz 37:467-472

18. Gayet CA (1875) Affection encéphalique (encéphalite diffuse probable) localisée aux étages supérieurs des pédoncules cérébraux et aux couches optiques, ainsi qu'au plancher du quatrième ventricule et aux parois latérales du troisième. Observation recueillie. Arch Physiol Norm Pathol 2:341-351

19. Wernicke C. Die acute, hämorrhagische Polioencephalitis superior. In: Wernicke C, ed. Lehrbuch der Gehirnkrankheiten für Aertze und Studirende. Kassel \& Berlin: Theodor Fischer, 1881: 229-242

20. Korsakoff S (1887) Ob alkogol'nom paraliche. Vestnik Klinicheskoi I Sudebnoi Psikhiatrii I Nevropatologii 4:1-102

21. Victor M, Yakovlev PISS (1955) Korsakoff's psychic disorhic disorder in conjunction with peripheral neuritis; a translation of Korsakoff's original article with comments on the author and his contribution to clinical medicine. Neurology 5:394-406

22. Pearce JMS (2005) Poliomyelitis (Heine-Medin disease). J Neurol Neurosurg Psychiatry 76:128

23. de la Monte SM, Kril JJ (2014) Human alcohol-related neuropathology. Acta Neuropathol 127:71-90

24. Oettinger W (1885) Etude sur les paralysies alcooliques (névrite multiples chez les alcooliques). Faculté de Médecine, Paris

25. Gombault A (1886) Sur les lésions de la névrite alcoolique. C R Hebd Acad Sci 102:439-440

26. Tabaraud F, Vallat JM, Hugon J, Ramiandrisoa H, Dumas M, Signoret JL (1990) Acute or subacute alcoholic neuropathy mimicking Guillain-Barré syndrome. J Neurol Sci 97:195-205

27. Bureau Y, Barrière H, Kerneis JP, De Ferron A (1957) Acropathies ulcéromutilantes pseudosyringomyéliques non familiales des membres inférieurs. Presse Med 65:2127-2132

28. Julian T, Glascow N, Syeed R, Zis P (2019) Alcohol-related peripheral neuropathy: a systematic review and meta-analysis. J Neurol 266:2907-2919

29. Hanewinckel R, van Oijen M, Ikram MA, van Doorn PA (2016) The epidemiology and risk factors of chronic polyneuropathy. Eur J Epidemiol 31:5-20

30. Bontius J. De paralyseos quadam specie, quam indigena Beriberÿ vocant. In: Bontius J, ed. De Medicina Indorum, Liber IV. Lugduni Batavia: F. Hackium, 1642: 115-120

31. Dangerfield HV. Le béribéri. Définition, étymologie, historique, bactériologie, symptomatologie, pathogénie, pathologie expérimentale, traitement. Paris: A. Maloine, 1905

32. Scheube B (1894) Die Berirberi-Krankheit. Gustav Fischer, Eine geographisch-medicinische Studie. Jena

33. Leroy de Méricourt A. Béribéri. In: Dechambre A, ed. Dictionnaire encyclopédique des sciences médicales. Paris: Masson \& Fils-Asselin, 1864: 129-165

34. Rogers C (1808) Disputation inauguralis medica quaedam de hydrope asthmatico, in ceylonia grassante, beri-beria dicto. Abernethy \& Walker, Edinburgh

35. Jeanselme E (1906) Le béribéri. Masson \& Cie-Gauthier-Villars, Paris

36. Kumar N (2007) Nutritional neuropathies. Neurol Clin 25:209-255 
37. Wernich. Geographisch-medicinische Studien nach den Erlebnissen einer Reise um die Erde. Berlin: August Dirschwald, 1878

38. Vedder EB. Beriberi. New York: William Wood \& Cie, 1913

39. Takaki K (1885) On the cause and prevention of kak'ke. Trans Seu-I-Kwai 39:29-37

40. Hawk A (2006) The great disease enemy, Kak'ke (beriberi) and the Imperial Japanese Army. Milit Med 171:333-339

41. De Lacerda JB (1883) Etiologia e genesis do beriberi. Livraria Contemporânea de Faro \& Lino, Rio de Janeiro

42. Eine Eijkman C, Krankheit Beri Beri-ähnliche (1997) Eine Beri Beri-ähnliche Krankheit der Hühner. Virchows Arch 148:523-532

43. Pietrzak K (2019) Christiaan Eijkman (1856-1930). J Neurol 266:2893-2895

44. Funk C. The etiology of the deficiency diseases. Beriberi, polyneuritis in birds, epidemic dropsy, scurvy, experimental scurvy in animals, infantile scurvy, ship beri-beri, pellagra. J State Med 1911;20 s:341-368

45. Eijkman C (1929) Antineuritic vitamin and beriberi. The Nobel Prize in Physiology or Medicine, Nobel lectures

46. Becker DA, Balcer LJ, Galetta SL (2012) The neurological complications of nutritional deficiency following bariatric surgery. $\mathrm{J}$ Obes 2012:608534

47. Thiéry F. Description d'une maladie, appelée mal de la rosa. J Med Chir Pharma 1755;2:337-346

48. Rocamora JP, Martinez FF. Dr. Gaspar Casàl (Siglo XVIII). Mal de la rosa. Su historia-Causa-Casos-Curación. Barcelona: Masnou, 1936

49. Frapolli F. Animadversiones in morbum, vulgo pelagram. Milan: J. Galeatium, 1771

50. Barrett-Connor E (1967) The etiology of pellagra and its significance for modern medicine. Am J Med 42:859-867

51. McConnell RB, Cheetham HD (1952) Acute pellagra during isoniazid therapy. Lancet 2:959-960

52. Narasimha VL, Ganesh S, Reddy S et al (2019) Pellagra and alcohol dependence syndrome: findings from a tertiary care addiction treatment centre in India. Alcohol Alcohol 54:148-151

53. Leigh D (1952) Pellagra and the nutritional neuropathies: a neuropathological review. J Ment Sci 98:130-142

54. Dejerine J (1881) Sur les altérations des nerfs cutanés dans la pellagre. C R Hebd Acad Sci 93:91-92

55. Wilson SAK. Neurology. London: E. Arnold, 1940

56. Strachan H (1888) Malarial multiple peripheral neuritis. Annu Univers Med Sci 1:139-141

57. Strachan H (1897) On a form of multiple neuritis prevalent in the West Indies. Practitioner 59:477-484

58. Scott HH (1918) An investigation into an acute outbreak of "central neuritis'. Ann Trop Med Parasitol 12:109-196

59. Netto AB, Netto CM, Mahadevan A, Taly AB, Agadi JB (2016) Tropical ataxic neuropathy-A century old enigma. Neurol India 64:1151-1159

60. Adamolekun B (2011) Neurological disorders associated with cassava diet: a review of putative etiological mechanisms. Metab Brain Dis 26:79-85

61. Borrajero I, Perez JL, Dominguez C et al (1994) Epidemic neuropathy in Cuba: morphological characterization of peripheral nerve lesions in sural nerve biopsies. J Neurol Sci 127:68-76

62. Macias-Matos C, Rodriguez-Ojea A, Chi N, Jimenez S, Zulueta D, Bates CJ (1996) Biochemical evidence of thiamine depletion during the Cuban neuropathy epidemic, 1992-1993. Am J Clin Nutr 64:347-353

63. Gonzalez-Quevedo A, Santiesteban-Freixas R, Eells JT, Lima L, Sadun AA (2018) Cuban Epidemic Neuropathy: insights into the toxic-nutritional hypothesis through international collaboration. MEDICC Rev 20:27-31

64. Fu Liong H, Santhi DP, Shanthi V, Mohd Hanip R (2014) Myanmarese Neuropathy: Clinical Description of acute peripheral neuropathy detected among Myanmarese refugees in Malaysia. Int Sch Res Notices 2014:187823

65. Chen KT, Twu SJ, Chiou ST, Pan WH, Chang HJ, Serdula MK (2003) Outbreak of beriberi among illegal mainland Chinese immigrants at a detention center in Taiwan. Public Health Rep 118:59-64

66. Ahoua L, Etienne W, Fermon F et al (2007) Outbreak of beriberi in a prison in Cote d'Ivoire. Food Nutr Bull 28:283-290

67. Smith TM, Austin C, Green DR et al (2018) Wintertime stress, nursing, and lead exposure in Neanderthal children. Sci Adv $4: 9483$

68. Hernberg S (2000) Lead poisoning in a historical perspective. Am J Ind Med 38:244-254

69. Hanna-Attisha M, Lanphear B, Landrigan P (2018) Lead poisoning in the 21st century: The silent epidemic continues. Am J Public Health 108:1430

70. Tanquerel des Planches L. Traités des maladies de plomb ou saturnines, suivi de l'indication des moyens qu'on doit mettre en usage pour se préserver de l'influence délétère des préparations de plomb, et de figures explicatives. Paris: Ferra, 1839

71. Duchenne (de Boulogne) GB. Electrisation localisée, 3rd ed. Paris: J. B. Baillières, 1872

72. Dejerine-Klumpke A (1889) Des polynévrites en général et des paralysies et atrophies saturnines en particulier. Félix Alcan, Etude clinique et anatomo-pathologique. Paris

73. De Mézeray F. Abrégé chronologique de l'histoire de France. Amsterdam: J. Covens \& C. Mortier, 1722

74. Bjørklund G, Oliinyk P, Lysiuk R et al (2020) Arsenic intoxication: general aspects and chelating agents. Arch Toxicol 94:1879-1897

75. Kelynack TN, Kirkby W (1901) Arsenical poisoning in beer drinkers. Baillière, Tyndall \& Cox, London

76. Spencer PS, Schaumburg HH, Sabri MI, Veronesi B (1980) The enlarging view of hexacarbon neurotoxicity. Crit Rev Toxicol 7:279-356

77. Chaqda M, El Mellakh M, Kissani N, Louhab N (2019) Neuropathy caused by addictive inhalation of $n$-hexane in glue sniffers. Presse Med 48:568-572

78. Morgan JP, Tulloss TC (1976) The Jake Walk Blues A toxicologic tragedy mirrored in American popular music. Ann Intern Med 85:804-808

79. Senanayake N, Jeyaratnam J (1981) Toxic polyneuropathy due to gingili oil contaminated with tri-cresyl phosphate affecting adolescent girls in Sri Lanka. Lancet 1:88-89

80. Calderon-Gonzalez R, Rizzi-Hernandez H (1967) Buckthorn polyneuropathy. N Engl J Med 277:69-71

81. Aldridge WN. The toxic oil syndrome (TOS, 1981): from the disease towards a toxicological understanding of its chemical aetiology and mechanism. Toxicol Lett 1992;64-65(Spec No):59-70

82. Swygert LA, Back EE, Auerbach SB, Sewell LE, Falk H (1993) Eosinophilia-myalgia syndrome: mortality data from the US national surveillance system. J Rheumatol 20:1711-1717

83. Allen JA, Peterson A, Sufit R et al (2011) Post-epidemic eosinophilia-myalgia syndrome associated with L-tryptophan. Arthritis Rheum 63:3633-3639

84. Wolfe WH, Lathrop GD, Albanese RA, Moynahan PM (1985) An epidemiologic investigation of health effects in Air Force personnel following exposure to herbicides and associated to dioxin. Chemosphere 14:707-716

85. Young AL, Kang HK, Shepard BM (1983) Chlorinated dioxins as herbicide contaminants. Environ Sci Technol 17:530A-540A

86. Poland AP, Smith D, Metter G, Possick P (1971) A health survey of workers in a 2,4-D and 2,4,5-T plan with special attention to chloracne, porphyria cutanea tarda, and psychologic parameters. Arch Environ Health 22:316-327 
87. Lathrop GD, Wolfe WH, Albanese RA, Moynahan PM (1982) Epidemiologic investigation of health effects in Air Force personnel following exposure to herbicides: study protocol. US Air Force School of Aerospace Medicine, Brooks Air Force Base

88. Michalek JE, Ketchum NS, Longnecker MP (2001) Serum dioxin and hepatic abnormalities in veterans of Operation Ranch Hand. Ann Epidemiol 11:304-311
89. Kim JS, Lim HS, Cho SI, Cheong HK, Lim MK (2003) Impact of Agent Orange exposure among Korean Vietnam veterans. Ind Health 41:149-157

90. Yi SW, Ohrr H, Hong JS, Yi JJ (2013) Agent Orange exposure and prevalence of self-reported diseases in Korean Vietnam veterans. J Prev Med Public Health 46:213-225 